\title{
MENINGKATKAN HASIL BELAJAR SISWA PADA KOMPETENSI DASAR TATA SURYA PELAJARAN IPA MENGGUNAKAN MODEL CONTEXTUAL TEACHING AND LEARNING (CTL) DI KELAS IV SD NEGERI 060819 KEC. MEDAN KOTA
}

\author{
Lasma Situmorang
}

Surel: lasmasitumorang@gmail.com

\begin{abstract}
ABSTRAK
Metode pembelajaran yang dipakai dalam penelitian ini adalah dengan menggunakan model pembelajaran kontekstual berbasis karakteristik Contextual Teaching and Learning (CTL). Hasil penelitian diperoleh ratarata nilai pada saat pretes sebesar 48,06 dan meningkat menjadi 69,35 pada siklus I kemudian pada hasil tes siklus II meningkat menjadi 79,68. Pada siklus II diperoleh tingkat ketuntasan belajar siswa sebesar 93,55\% dan tingkat ketercapaian tes hasil belajar mencapai $90 \%$ atau dengan kata lain setelah dilakukan siklus II siswa secara keseluruhan telah mencapai standar ketuntasan belajar di atas 70\%. Dengan demikian dapat disimpulkan bahwa penggunaan model pembelajaran kontekstual dapat meningkatkan hasil belajar siswa pada aspek kognitif kompetensi Tata Surya di Kelas IV SD Negeri 060819 Kec. Medan Kota.
\end{abstract}

Kata Kunci: Hasil Belajar, Model Contextual Teaching And Learning (CTL), Tata Surya

\section{PENDAHULUAN}

Pendidikan adalah investasi besar jangka panjang yang harus ditata, disiapkan dan diberi sarana maupun prasarananya dalam arti modal material yang cukup besar, Terkait dengan mutu pendidikan pada jenjang Sekolah Dasar (SD) sampai saat ini masih jauh dari apa yang kita harapkan, terutama pada kualitas pembelajaran. Pendidikan tidak lepas dari pembelajaran. Muhibbinsyah (2003:59) menyatakan bahwa yang paling vital dalam setiap usaha pendidikan adalah belajar, sehingga tanpa belajar sesungguhnya tak pernah ada pendidikan. Dengan belajar setiap orang akan mengalami perubahan dan dapat berkembang lebih baik dari makhluk lain, serta dapat mempertahankan kehidupannya ditengah-tengah perkembangan zaman yang semakin maju dan persaingan yang sangat ketat seperti sekarang ini. Indikator utama yang digunakan untuk menilai kualitas pembelajaran dan kelulusan siswa dari suatu lembaga pendidikan, sering didasarkan pada hasil belajar siswa yang tertera pada nilai tes hasil belajar. 
Dalam Kegiatan Belajar
Mengajar (KBM), guru sudah
berupaya menyampaikan materi
dengan rinci dan jelas, terutama pada
pelajaran Sains. Dalam proses
pembelajaran guru di sekolah telah
berusaha dengan maksimal,
kenyataannya di lapangan hasil
belajar para siswa tidak sesuai dengan
apa yang diharapkan, khususnya pada
kompetensi Tata Surya.
Pemahaman para siswa pada kompetensi Tata Surya masih sangat rendah. Dari hasil pembelajaran yang diterapkan oleh guru Kelas IV SD Negeri 060819 Kec. Medan Kota pada kompetensi Tata Surya hanya mencapai $35,48 \%$ dari 31 siswa, berarti $64,52 \%$ siswa belum mencapai standar ketuntasan belajar yang diharapkan. Guru Kelas IV mengemukakan standar ketuntatasan belajar minimal $70 \%$ dari keseluruhan siswa dan siswa dapat dikatakan tuntas dalam belajar minim: ${ }^{-}$ memperoleh nilai 70 , mengemukaka ketuntasan belajar dapat diartikan sebagai pendekatan dalam pembelajaran yang mempersyaratkan peserta didik dalam menguasai secara tuntas standar kompetensi, kompetensi dasar dan indikator yang telah ditetapkan dan kriteria ideal ketuntasan untuk masing-masing indikator minimal 70\%. Banyak usaha yang dapat dilakukan untuk meningkatkan kualitas hasil dari pembelajaran melalui peningkatan penguasaan/pemahaman materi, menggunakan pendekatan dan metode yang tepat, penggunaan media dan alat pembelajaran yang menarik bagi siswa, menggunakan berbagai macam strategi pembelajaran dan sebagainya. Nurdin, S. (2005) menyatakan "kendala yang masih dirasakan oleh guru belum mampu mengoptimalkan sumber dan media pembelajaran untuk membantu kegiatan pembelajaran sesuai dengan yang diharapkan".

Pada penelitian ini peneliti merancang usaha meningkatkan hasil belajar siswa dengan menggunakan Pendekatan Pembelajaran Kontekstual (Contekstual Teaching and Learning). "Pembelajaran kontekstual merupakan suatu pendekatan dalam pembelajaran yang membantu pendidik mengaitkan antara materi yang diajarkan dengan situasi dunia nyata siswa dan mendorong siswa membuat hubungan antara pengetahuan yang dimilikinya dengan penerapannya dalam kehidupan mereka sebagai anggota keluarga dan masyarakat", Rivai (2007). Peneliti berkeinginan untuk memperbaiki pembelajaran Sains pada kompetensi Tata Surya dengan menggunakan model pembelajaran kontekstual.

Tujuan Penelitian Tindakan Kelas ini adalah sebagai berikut:

1. Untuk meningkatkan hasil belajar siswa pada kompetensi Tata Surya 
di Kelas IV SD Negeri 060819 Kec. Medan Kota.

2. Untuk keterampilan guru dalam menggunakan model pembelajaran kontekstual di Kelas IV SD Negeri 060819 Kec. Medan Kota.

\section{METODE PENELITIAN}

Penelitian ini berlokasi di SD Negeri 060819 Kec. Medan Kota. Penelitian ini dilaksanakan pada bulan Januari s.d Maret 2016. Kegiatan penelitian dilaksanakan dalam 2 siklus yaitu siklus I dilaksanakan 2 kali pertemuan dan siklus II dilaksanakan 2 kali pertemuan.

Subjek penelitian tindakan kelas ini adalah siswa Kelas IV SD Negeri 060819 Kec. Medan Kota yang berjumlah 31 siswa. Pelaksanaan penelitian tindakan kelas ini dilaksanakan selama dua siklus, setiap siklus terdiri dari kegiatan perencanaan, tindakan, observasi dan refleksi/ evaluasi.

Kemmis dan Taggart mengemukakan dalam Wiriaatmadja (2007:66-67) model penelitian tindakan kelas terdiri dari 4 komponen, yaitu: (1) perencanaan (plan), (2) tindakan (act), (3) pengamatan (observe), dan (4) Refleksi (reflect)'.

Penelitian tindakan kelas ini dilakukan dalam bentuk kolaborasi antara peneliti dengan guru kelas. Dalam hal ini sebelum peneliti tampil di depan siswa untuk mengajar (act), terlebih dahulu peneliti melihat penampilan guru kelas dalam mengajar. Sebelum memasuki siklus I, peneliti terlebih dahulu mengidentifikasi masalah pembelajaran di Kelas IV pada bidang studi IPA. Masalah yang ditemui yaitu: (1) rendahnya hasil belajar Sains pada kompetensi Tata Surya, (2) kurangnya pemahaman siswa pada kompetensi Tata Surya, (3) keaktifan siswa dalam proses belajar mengajar masih kurang dan metode/pendekatan pembelajaran yang digunakan belum sesuai.

Sesuai dengan pelaksanaan penelitian, yang digunakan untuk mengumpulkan data dengan menggunakan lembar pengamatan pelaksanaan pembelajaran kontekstual, lembar catatan lapangan, tes objektif dalam bentuk esay tes serta photo digital.

Untuk mengetahui sejauh mana keefektifan pelaksanaan karakteristik pembelajaran kontekstual yang dilaksanakan oleh guru dalam tindakan, maka peneliti mempersiapkan lembar pengamatan pelaksanaan pembelajaran kontekstual serta lembar catatan lapangan. Hal tersebut dapat dilihat pada tabel 2 dan 3 .

Pengembangan instrumen tes objektif dalam bentuk esay tes 
meliputi kisi-kisi soal dan item pada kompetensi "Tata Surya" sesuai dengan Kurikulum.

$\mathrm{C}_{1}$ : aspek pengetahuan

$\mathrm{C}_{4}$ : aspek analisis

$\mathrm{C}_{2}$ : aspek pemahaman

$\mathrm{C}_{5}$ : aspek sintesis

$\mathrm{C}_{3}$ : aspek penerapan

$\mathrm{C}_{6}$ : aspek evaluasi

Analisis data yang dipakai dalam penelitian ini adalah analisis kualitatif data dan analisis persentase.

1. Analisis Kualitatif Data

Dalam analisis kualitatif data peneliti menggunakan model Miles dan Huberman dalam Sugiyono (2008:337). Analisis data yang dilakukan pada saat pengumpulan data berlangsung dan setelah selesai pengumpulan data dalam periode tertentu. Analisis data dilakukan dengan langkah, yaitu: data reduction, data display dan conclusion drawing/verification.

a. Data Reduction (Reduksi Data)

Proses reduksi data dilakukan dengan merangkum data, memilih hal-hal yang pokok dari data dan memfokuskan pada hal-hal yang penting.

b. Data Display (Penyajian Data) Penyajian data dilakukan dalam bentuk teks yang bersifat naratif dan diagram.

\section{c. Conclusion}

Verification

$\begin{array}{lrr} & \text { Kesimpulan } & \text { yang } \\ \text { dibuat } & \text { berdasarkan } & \text { temuan } \\ \text { yang } & \text { sebelumnya } & \text { belum } \\ \text { pernah ada, temuan tersebut } & \text { ad } \\ \text { berupa deskripsi yang jelas. }\end{array}$

2. Analisis Persentase

Analisis data ini dilakukan untuk mengetahui berhasil atau tidaknya tindakan yang dilakukan dalam penelitian ini. Hal ini dilihat dari seberapa persentasi keberhasilan yang dicapai dilihat dari aktivitas belajar.

Dengan rumus:

$\frac{\text { Jumlahsiswa yang mengalami perubahan }}{\text { Jumlah siswakeseluruhan }} \times 100 \%$

\section{HASIL DAN PEMBAHASAN}

Langkah awal yang dilakukan oleh peneliti adalah mengidentifikasi masalah ke lokasi penelitian. Terlebih dahulu peneliti menemui kepala sekolah SD Negeri 060819 Kec. Medan Kota di ruangan kepala sekolah untuk meminta izin melakukan observasi di Kelas IV guna mengidentifikasi masalah pembelajaran yang akan diteliti nantinya.

Berdasarkan hasil wawancara peneliti dengan guru Kelas IV SD Negeri 060819 Kec. Medan Kota, maka permasalahan yang akan diatasi adalah rendahnya hasil belajar siswa pada kompetensi Tata Surya. Untuk 
meningkatkan hasil belajar siswa pada aspek kognitif, peneliti menggunakan model pembelajaran kontekstual berbasis karakteristik Contextual Teaching and Learning (CTL).

Pada pertemuan awal siswa diberikan pretes sebelum diberikan pembelajaran, untuk mengetahui kemampuan awal siswa pada materi tentang Tata Surya. Hasil pretes siswa, diperoleh simpulan bahwa siswa masih tergolong kurang dalam menyelesaikan soal-soal Tata Surya. Kesulitan-kesulitan siswa tersebut dapat dilihat dari kesalahan-kesalahan yang dilakukan siswa. Berikut disajikan persentase jawaban siswa dari soal-soal yang diberikan pada saat pretes.

Dan jawaban menunjukkan bahwa dari 10 soal yang diujikan kepada 31 siswa, keseluruhannya masih tergolong belum berhasil. Selain memberikan pretes guru memberikan pertanyaan lisan kepada siswa mengenai materi Tata Surya. Hasil jawaban siswa pada prestes dan pertanyaan-pertanyaan yang diberikan, menunjukkan bahwa siswa masih mengalami kesulitan dalam menyelesaikan soal dan kurang memahami materi Tata Surya, diantaranya:

1. Siswa belum mengetahui berbagai susunan planet dalam Tata Surya.

2. Siswa belum memahami pentingnya Tata Surya.
3. Siswa belum bisa menganalisis susunan planet dalam Tata Surya.

4. Siswa belum mengetahui susunan planet dalam Tata Surya.

5. Siswa belum dapat menentukan susunan planet dalam Tata Surya

Secara ringkas tingkat keberhasilan awal siswa saat diberikan pretes dapat dilihat bahwa rata-rata nilai siswa masih memiliki tingkat keberhasilan di bawah $70 \%$ yaitu rata-rata sebesar 48,06 sehingga secara perorangan hanya ada 8 orang yang sudah mencapai keberhasilan. Kemampuan awal siswa masih tergolong belum berhasil dalam belajar. Dengan demikian, dapat dinyatakan bahwa kemampuan awal siswa masih rendah dalam materi Tata Surya.

Setelah diketahui kesulitankesulitan yang dialami siswa, selanjutnya peneliti bersama guru kelas merancang suatu alternatif pemecahan masalah bagi siswa sebagai berikut:

a. Merancang media pembelajaran yang digunakan nantinya untuk menjelaskan kepada siswa tentang susunan planet dalam Tata Surya.

b. Sebelum menjelaskan materi, guru terlebih dahulu menanyakan kepada siswa macam benda langit.

c. Guru menjelaskan materi susunan planet dalam Tata Surya dan upaya yang dilakukan untuk menjaga kelestariannya dengan 
memberikan beberapa contoh planet kepada siswa.

d. Guru menyuruh siswa untuk duduk secara berkelompok dalam mengerjakan tugas dari guru agar siswa dapa $t$ bertukar pendapat.

e. Setelah 30 menit setiap kelompok membacakan hasil kerjanya masing-masing di depan kelas.

f. Pada akhir pembelajaran, guru menyimpulkan materi yang telah dipelajari dan memberikan tugas kepada siswa.

$\begin{array}{rrr}\text { Sudah } & \text { ada } & \text { Rencana } \\ \text { Pelaksanaan } & & \text { Pembelajaran }\end{array}$

Kontekstual dengan materi Tata Surya untuk dilaksanakan, sudah ada lembar pengamatan pelaksanaan pembelajaran kontekstual yang digandakan sebanyak 3 lembar, sudah ada lembar catatan lapangan yang digandakan sebanyak 3 lembar dan tes objektif dalam bentuk esay tes yang mengacu pada kisi-kisi soal telah digandakan sebanyak 35 lembar.

Pada kegiatan ini yang menerapkan pembelajaran kontekstual adalah peneliti. Materi yang diajarkan pada tindakan ini adalah Tata Surya.

Tindakan yang dilakukan adalah sebagai berikut:

\section{Pertemuan 1}

1. Sebelum guru menyampaikan materi pelajaran yang akan dipelajari siswa, terlebih dahulu guru menyampaikan tujuan pembelajaran yang harus dicapai oleh siswa, yaitu:

a. Siswa dapat menyebutkan nama-nama planet dalam Tata Surya.

b. Siswa dapat menyebutkan susunan planet dalam Tata Surya.

c. Siswa dapat menyebutkan pentingnya susunan planet dalam Tata Surya.

d. Siswa menyebutkan macammacam Tata Surya.

e. Siswa dapat menjelaskan susunan planet dalam Tata Surya.

2. Sebagai pembukaan, guru menanyakan kepada siswa tentang:

a. Susunan planet dalam Tata Surya.

b. Sifat dan keadaan planet.

3. Siswa dibagi dalam 6 kelompok belajar, masing-masing kelompok terdiri dari 4-5 siswa yang heterogen agar suasana kelas terlihat menyenangkan.

4. Siswa menerima media pembelajaran berupa macammacam benda langit dan lembar kerja kelompok.

5. Berdasarkan pengetahuan dan pengalaman masing-masing siswa, dalam kelompok belajar siswa mengerjakan tugas kelompok. 
6. Siswa mengelompokkan susunan planet dalam Tata Surya dalam tabel yang telah tersedia.

7. Siswa membuat catatan tentang pengelompokkan susunan planet dalam Tata Surya sesuai dengan pemahamannya masing-masing.

8. Setelah 30 menit bekerja, siswa membacakan hasil temuannya di depan kelas tiap kelompok belajar.

9. Guru memberikan komentar terhadap temuan siswa.

10. Dengan cara 'sharing' siswa yang menyebutkan sebanyak mungkin contoh susunan planet dalam Tata Surya.

11. Sebagai kegiatan akhir, guru menyimpulkan materi yang telah dipelajari.

\section{Pertemuan 2}

1. Sebelum guru menyampaikan materi pelajaran yang akan dipelajari siswa, terlebih dahulu guru menyampaikan tujuan pembelajaran yang harus dicapai oleh siswa, yaitu:

a. Siswa dapat menyebutkan nama-nama planet dalam Tata Surya.

b. Siswa dapat menyebutkan susunan planet dalam Tata Surya.

c. Siswa dapat memahami pentingnya susunan planet dalam Tata Surya. d. Siswa menyebutkan jenisjenis planet Tata Surya.

e. Siswa dapat menyebutkan susunan planet dalam Tata Surya.

2. Sebagai pembukaan, guru menanyakan kepada siswa tentang:

a. Macam-macam benda langit.

b. Usaha-usaha yang dilakukan untuk menjaga alam.

3. Siswa dibagi dalam 6 kelompok belajar, masing-masing kelompok terdiri dari 4-5 siswa yang heterogen agar suasana kelas terlihat menyenangkan.

4. Siswa menerima media pembelajaran berupa gambargambar tempat Tata Surya dan lembar kerja kelompok.

5. Berdasarkan pengetahuan dan pengalaman masing-masing siswa, dalam kelompok belajar siswa mengerjakan tugas kelompok.

6. Siswa membuat catatan tentang Tata Surya.

7. Setelah 30 menit bekerja, siswa membacakan hasil temuannya di depan kelas tiap kelomok belajar.

8. Guru memberikan komentar terhadap temuan siswa.

9. Dengan cara 'sharing' siswa menyebutkan susunan planet dalam Tata Surya.

10. Sebagai kegiatan akhir, guru menyimpulkan materi yang telah 
dipelajari dan siwa mengerjakan tes objektif.

Pengamatan dilakukan oleh guru Kelas IV dan dibantu guru Kelas, dengan tujuan apakah penerapan tindakan telah sesuai dengan skenario pembelajaran yang dirancang. Berdasarkan hasil pengamatan pada siklus I dengan 2 kali pertemuan adalah guru belum optimal dalam melaksanakan tindakan. Terutama pada penggunaan karakteristik pembelajaran kontekstual.

Peneliti bersama guru Kelas IV berkumpul untuk merefleksi tindakan yang telah dilaksanakan oleh peneliti. Dari hasil refleksi, dapat disimpulkan ada 5 karakteristik pembelajaran kontekstual yang kurang optimal diterapkan dalam tindakan, antara lain yaitu pada point 2 (materi pelajaran yang diajarkan belum terlihat menunjang terhadap kehidupan siwa sehari-hari), point 6 (siswa belum menggunakan berbagai sumber belajar yang ada), point 9 (dalam proses pembelajaran siswa belum terlihat kritis dalam belajar), point 10 (belum ada terlihat hasil karya siswa pada dinding kelas), dan pada point 11 (Belum ada laporan hasil karya siswa yang dibawa siswa untuk diberitahukan kepada orang tuanya). Serta hal-hal yang terjadi di lapangan yaitu (1) dalam pengelolaan kelas belum optimal karena siswa masih ribut pada saat pembentukan kelompok belajar, (2) media pembelajaran (gambar Tata Surya) kurang banyak dan tidak berwarna, (3) bahan ajar yang dipakai masih kurang, (4) pembagian kelompok belajar belum merata, (5) belum mengoptimalkan pemanfaatan papan tulis sebagai sarana dalam belajar, (6) dalam pelaksanaan tindakan guru tidak menerapkan kegiatan inti pada RPP (siswa secara berkelompok membacakan hasil temuannya di depan kelas).

Dari hasil refleksi, maka dapat dianalisis bahwa peneliti belum memiliki pengalaman mengajar. Dalam hal ini maka dapat diprediksikan ke depan tentang penerapan pembelajaran kontekstual yang optimal yaitu dengan cara (1) mengaitkan materi ajar dengan kehidupan siswa sehari-hari, (2) dalam KBM siswa dapat menggunakan berbagai macam sumber belajar antara lain temannya sendiri, koran, majalah, televisi dan lain-lain, (3) guru harus merangsang siswa agar bertanya tentang materi yang dipelajarinya. Dengan demikian siswa menjadi kritis dalam berfikir, (4) setelah KBM selesai, hasil karya siswa harus dilengketkan pada dinding, agar siswa bangga terhadap hasil karyanya, (5) sebelum proses pembelajaran dilaksanakan, siswa seharusnya membentuk kelompok belajar terlebih dahulu agar 
tidak ribut, (6) guru menyediakan media gambar yang banyak agar setiap siswa memperolehnya dan berwarna sehingga siswa lebih termotivasi lagi untuk belajar, (7) dalam pembagian kelompok harus merata (terdapat 1 kelompok belajar berjumlah 6 orang siswa dan 5 kelompok belajar berjumlah masingmasing 5 orang siswa), (8) dalam proses pembelajaran, guru harus memanfaatkan papan tulis sebagai sarana pembelajaran, (9) guru tidak menerapkan kegiatan inti pada Rencana Kegiatan Pembelajaran Kontekstual dikarena alokasi waktu tidak cukup, untuk mengatasi hal tersebut seharusnya guru melengketkan hasil dari kerja masingmasing kelompok belajar siswa di papan tulis agar dilihat oleh siswa lain pada saat jam istirahat.

Evaluasi dilakukan pada akhir pertemuan siklus I setelah semua materi diajarkan, siswa kembali diberikan tes untuk mengetahui sejauh mana perkembangan hasil belajar siswa. Secara ringkas tingkat keberhasilan belajar siswa.

Terlihat pada hasil tes berikutnya bahwa terdapat 12 orang siswa $(38,71 \%)$ yang belum tuntas dalam belajar yaitu memiliki tingkat ketuntasan belajar di bawah 70\% dan sebanyak 19 orang $(61,29 \%)$ yang telah mencapai standar ketuntasan belajar atau rata-rata kelas sebesar 69,35. Dengan demikian dapat diketahui bahwa kemampuan siswa dalam memahami materi Tata Surya berdasarkan tingkat keberhasilan secara keseluruhan masih tergolong belum tuntas yaitu hanya mencapai standar belajar $61,29 \%$. Berikut persentase tingkat ketercapaian hasil belajar siswa pada tes hasil belajar siklus I menunjukkan bahwa dari 10 soal tes hasil yang diberikan kepada siswa sudah 6 soal $(60 \%)$ yang dapat diselesaikan siswa dengan baik dan termasuk telah berhasil (di atas 70\% siswa menjawab dengan benar), sedangkan $40 \%$ lagi tidak dapat diselesaikan siswa dengan baik (belum berhasil) yaitu soal nomor 2, 3, 5 dan 10 .

Dengan demikian dapat dinyatakan bahwa tingkat ketercapaian hasil belajar siswa pada siklus I secara keseluruhan soal masih tergolong belum berhasil. Dari tes yang diberikan dalam bentuk esay, ternyata 6 soal yang dapat diselesaikan dengan baik, sementara 4 soal lainnya tidak dapat diselesaikan dengan baik. Untuk memastikan letak kesulitan yang dialami siswa saat mengerjakan tes hasil belajar, maka dilakukan wawancara langsung khususnya dengan siswa yang mengalami kesulitan. Hasil wawancara, diperoleh bahwa siswa mengalami kesulitan menyelesaikan soal karena:

1. Siswa belum mengetahui susunan planet dalam Tata Surya. 
2. Siswa belum memahami pentingnya mengetahui susunan planet dalam Tata Surya.

3. Siswa belum mampu mengevaluasi susunan planet dalam Tata Surya.

Berdasarkan hasil refleksi, evaluasi dan analisis data pada siklus I, masalah yang perlu diperbaiki adalah tentang hasil belajar siswa belum mencapai standar minimal dalam ketuntasan belajar. bahan ajar yang dipakai masing kurang, pembagian kelompok belajar belum merata, belum mengoptimalkan pemanfaatan papan tulis sebagai sarana dalam belajar, dalam pelaksanaan tindakan guru tidak menerapkan kegiatan inti pada RPP (siswa secara berkelompok membacakan hasil temuannya di depan kelas).

Dalam hal perencanaan yang dilakukan oleh peneliti adalah merancang RPP dengan menginovasi RPP pada siklus I agar tindakan yang dilakukan dapat terlaksana seoptimal mungkin, menganalisis soal dan memperbaiki tes, lembar pengamatan pelaksanaan pembelajaran kontekstual dan lembar catatan lapangan masih memakai bentuk dalam siklus I.

Tindakan yang dilakukan adalah sebagai berikut:

Pertemuan 3
1. Terlebih dahulu guru menyampaikan tujuan pembelajaran yang harus dicapai oleh siswa, yaitu:

a. Siswa dapat menyebutkan susunan planet dalam Tata Surya.

b. Siswa dapat menyebutkan pentingnya susunan planet dalam Tata Surya.

c. Siswa menyebutkan macammacam benda langit.

d. Siswa dapat mengungkapkan susunan planet dalam Tata Surya.

2. Sebagai pembukaan, guru menanyakan kepada siswa tentang:

a. Susunan planet dalam Tata Surya.

b. Sifat dan keadaan planet.

3. Siswa sudah membentuk kelompok belajar dalam 6 kelompok, masing-masing kelompok terdiri dari 4-5 siswa secara merata. Kelompok disusun secara heterogen agar tercipta suasana kelas yang menyenangkan.

4. Setiap siswa menerima media pembelajaran yaitu gambargambar berwarna Tata Surya dan lembar kerja kelompok.

5. Berdasarkan pengetahuan dan pengalaman masing-masing siswa, dalam kelompok belajar siswa mengerjakan tugas kelompok. 
6. Selain belajar berkelompok setiap siswa mengelompokkan susunan planet dalam Tata Surya dalam tabel yang dibuat sendiri dengan petunjuk guru kemudian mengerjakan tugas secara berkelompok.

7. Siswa membuat catatan tentang pengelompokkan susunan planet dalam Tata Surya sesuai dengan pemahamannya masing-masing.

8. Setelah 30 menit bekerja, siswa mengumpulkan hasil kerja kelompoknya masing-masing.

9. Guru memberikan komentar terhadap temuan siswa.

10. Dengan cara 'sharing' siswa menyebutkan sebanyak mungkin contoh susunan planet dalam Tata Surya.

11. Sebagai kegiatan akhir, guru menyimpulkan materi yang telah dipelajari dan melengketkan hasil kerja siswa dipapan tulis untuk dilihat para siswa.

Pertemuan 4

1. Terlebih dahulu guru menyampaikan tujuan pembelajaran yang harus dicapai oleh siswa, yaitu:

a. Siswa dapat menyebutkan nama-nama planet dalam Tata Surya.

b. Siswa dapat menyebutkan pentingnya susunan planet dalam Tata Surya. c. Siswa menyebutkan macammacam benda langit.

d. Siswa dapat menyebutkan jenis-jenis planet dalam Tata Surya.

2. Sebagai pembukaan, guru menanyakan kepada siswa tentang:

a. Macam-macam benda langit.

b. Usaha-usaha yang dilakukan menjaga alam.

3. Siswa sudah membentuk kelompok belajar dalam 6 kelompok, masing-masing kelompok terdiri dari 4-5 siswa secara merata. Dan kelompok disusun secara heterogen agar tercipta suasana kelas yang menyenangkan.

4. Setiap siswa menerima media pembelajaran berupa gambargambar berwarna tentang Tata Surya yang hampir punah dan lembar kerja kelompok serta membawa koran dan majalah dari rumah masing-masing siswa.

5. Berdasarkan pengetahuan dan pengalaman masing-masing siswa, dalam kelompok belajar siswa mengerjakan tugas kelompok, menggunting gambargambar benda-benda langit pada koran dan majalah yang dibawa dan digabungkan menjadi sebuah kliping dalam kerja kelompok.

6. Setelah 30 menit bekerja, masingmasing kelompok belajar siswa secara perwakilan mengumpulkan 
hasil kerja kelompoknya kelompok belajar.

7. Kemudian guru memberikan komentar terhadap temuan siswa.

8. Setelah itu guru melengketkan hasil kerja siswa secara berkelompok di papan tulis supaya para siswa melihat hasil karya temannya yang lain.

9. Sebagai kegiatan akhir, guru menyimpulkan materi yang telah dipelajari dan siswa mengerjakan tes objektif.

\section{Pelaksanaan pengamatan} dilakukan oleh guru Kelas IV dan guru Kelas IV. Dari hasil pengamatan yang dilakukan observer, bahwa tindakan yang dilakukan peneliti belum optimal pada karakteristik pembelajaran kontekstual yaitu masih sedikit hasil karya siswa yang dilengketkan pada dinding kelas, belum adanya hasil karya siswa yang dibagikan kepada siswa untuk dilaporkan pada orang tuanya dan pada saat proses pembelajaran berlangsung ada siswa yang ribut.

Dalam hal refleksi peneliti bersama 2 orang pengamat berkumpul untuk merefleksi tindakan yang telah dilaksanakan oleh peneliti. Dari hasil pengamatan tindakan yang dilaksanakan oleh peneliti setelah dibahas bersama-sama, karakteristik pembelajaran kontekstual yang dilaksanakan dalam tindakan sudah terlihat lebih baik dari tindakan pada
Siklus I. Masih ada terjadi kurang optimal penggunaan karakteristik pembelajaran kontekstual dalam tindakan yaitu masih sedikit hasil karya siswa yang dilengketkan pada dinding kelas. Serta hal-hal yang terjadi di lapangan yaitu dalam pengelolaan kelas belum optimal karena siswa masih ribut disaat ada siswa yang telah selesai mengerjakan tugas dari guru dan mengganggu temannya yang lain.

Hasil refleksi menunjukkan bahwa pembelajaran yang dilaksanakan peneliti menunjukan belum optimalnya dikarenakan peneliti belum memiliki pengalaman dalam mengajar khususnya siswa SD. Dalam hal ini maka dapat diprediksikan ke depan tentang penerapan pembelajaran kontekstual yang optimal yaitu dengan lebih teliti lagi peneliti dalam menerapkan tindakan.

Hasil evaluasi menerangkan bahwa tingkat keberhasilan belajar siswa pada aspek kognitif sudah mencapai standar ketuntasan belajar yang telah ditetapkan.

Terlihat bahwa terdapat 2 orang siswa $(6,45 \%)$ yang belum tuntas dalam belajar dan sebanyak 29 orang siswa $(93,55 \%)$ yang telah mencapai standar ketuntasan belajar atau rata-rata kelas sebesar 79,68. Dengan demikian dapat diketahui bahwa kemampuan siswa dalam memahami materi Tata Surya 
berdasarkan tingkat keberhasilan secara keseluruhan telah berhasil. Berikut persentase tingkat ketercapaian hasil belajar siswa pada tes hasil belajar siklus II.

Dari 10 soal tes hasil yang diberikan kepada siswa telah 9 soal (90\%) yang dapat diselesaikan siswa dengan siswa dengan baik dan termasuk telah berhasil (di atas $70 \%$ siswa menjawab dengan benar), sedangkan $10 \%$ lagi tidak dapat diselesaikan siswa dengan baik (belum berhasil) yaitu soal nomor 10 . Dengan demikian dapat dinyatakan bahwa tingkat ketercapaian hasil belajar siswa pada siklus II secara keseluruhan soal telah berhasil. Letak kesulitan yang dialami siswa saat mengerjakan tes hasil belajar setelah dilakukan wawancara langsung dengan siswa yang mengalami kesulitan adalah belum mampunya siswa menyebutkan macam-macam benda langit.

Sebelum tindakan ketuntasan hasil belajar siswa mencapai 8 orang siswa yaitu $25,81 \%$ dari 31 orang siswa dan setelah tindakan tingkat keberhasilan belajar siswa pada aspek kognitif mencapai standar ketuntasan belajar di atas $70 \%$ dengan jumlah siswa yang mencapai standar ketuntasan belajar mencapai 29 orang siswa yaitu $93,55 \%$ dari 31 orang siswa Kelas IV, dengan rata-rata nilai keseluruhan yang diperoleh 79,68. Hal ini menunjukkan ketuntasan belajar siswa mencapai di atas kriteria yang telah ditetapkan (70\%). Peningkatan ketuntasan hasil belajar dari pretes, postes siklus I dan postes siklus II adalah sebagai berikut

1. Ketuntasan hasil belajar siswa pada pretes mencapai 8 orang siswa yaitu $25,81 \%$ dari 31 orang siswa dengan rata-rata nilai 48,06.

2. Ketuntasan hasil belajar siswa pada postes siklus I mencapai 19 orang siswa yaitu $61,29 \%$ dari 31 orang siswa dengan rata-rata nilai 69,35. Penerapan pembelajaran, terlaksana sebanyak 6 karakteristik pembelajaran yaitu 54,55\% dari 11 karakteristik pembelajaran kontekstual.

3. Ketuntasan hasil belajar siswa pada postes siklus II mencapai 29 orang siswa yaitu $93,55 \%$ dari 31 orang siswa dengan rata-rata nilai 79,86. Penerapan pembelajaran, terlaksana sebanyak 9 karakteristik pembelajaran yaitu $81,82 \%$ dari 11 karakteristik pembelajaran kontekstual.

\section{Pembahasan Penelitian}

Penggunaan karakteristik pembelajaran kontekstual yang dilaksanakan peneliti telah terlaksana dengan optimal walaupun dalam pelaksanaannya siswa masih ada yang ribut pada proses pembelajaran. Karakteristik pembelajaran kontekstual jika dikaitkan dengan tujuh komponen pembelajaran 
kontekstual, dinyatakan masih ada kekurangan dalam komponen konstruktivisme (constructivism) dan bertanya (questioning). Dalam konstruktivisme siswa belum mampu menemukan dan menerapkan idenya sendiri melalui keterlibatan aktif dalam proses belajar mengajar. Dan dalam hal bertanya siswa belum terbiasa mengajukan pertanyaan kepada guru sehingga siswa enggan dan tidak tahu apa yang akan dipertanyakan.

Melalui penggunaan pembelajaran kontekstual dapat meningkatkan hasil belajar siswa pada aspek kognitif kompetensi Tata Surya. Hasil penelitian, pada saat pretes sebelum diberikan tindakan diperoleh nilai rata-rata kelas sebesar 48,06. Rata-rata daya serap siswa masih berada di bawah $70 \%$ dikatakan belum berhasil baik secara individu maupun secara keseluruhan. Setelah pemberian tindakan melalui penggunaan pembelajaran kontekstual yang dilakukan peneliti (siklus I) diperoleh nilai rata-rata kelas meningkat menjadi 69,35 dengan tingkat ketuntasan belajar siswa dari 31 orang siswa sebesar $61,29 \%$ dan tingkat ketercapaian tes hasil belajar sebesar $60 \%$. Berdasarkan analisis data siklus I diperoleh kesimpulan sementara bahwa penggunaan pembelajaran kontekstual yang dilakukan peneliti belum dapat meningkatkan hasil belajar siswa pada aspek kognitif kompetensi Tata Surya baik secara individu maupun keseluruhan, sehingga perlu perbaikan dan pengembangan pembelajaran kontekstual pada siklus II.

Pada tindakan siklus II, merupakan perbaikan pembelajaran yang dilaksanakan pada siklus I. Penggunaan pembelajaran kontekstual pada siklus II, peneliti menekankan tentang susunan planet dalam Tata Surya, pentingnya tentang susunan planet dalam Tata Surya serta. Dari tes hasil belajar diperoleh nilai rata-rata kelas meningkat menjadi 79.68 dengan ketuntasan belajar meningkat sebesar 93,55\% dan tingkat ketercapaian tes hasil belajar mencapai 90\%. Hal ini berarti pembelajaran dengan menggunakan model pembelajaran kontekstual yang dilaksanakan peneliti dapat meningkatkan hasil belajar siswa pada aspek kognitif kompetensi Tata Surya. Hal tersebut dapat dilihat pada tabel 15 tentang rata-rata nilai perubahan hasil belajar siswa saat pretes, postes pada siklus I dan postes.

\section{SIMPULAN}

Berdasarkan hasil penelitian yang telah dilaksanakan, maka diperoleh kesimpulan bahwa penggunaan model pembelajaran kontekstual dapat meningkatkan hasil belajar siswa pada aspek kognitif 
kompetensi Tata Surya di Kelas IV SD Negeri 060819 Kec. Medan Kota.

Hal ini terbukti dari:

1. Rata-rata nilai pada saat pretes sebesar 48,06 meningkat menjadi sebesar 69,35 pada siklus I dan meningkat menjadi 79,68 pada siklus II.

2. Sebelum dilaksanakan tindakan, hasil belajar siswa masih rendah dan belum berhasil. Setelah dilakukan tindakan pada siklus I diperoleh tingkat ketuntasan belajar $61,29 \%$ dengan tingkat ketercapaian tes hasil belajar sebesar $60 \%$ yang berarti secara keseluruhan siswa belum mencapai standar minimal ketuntasan belajar. Hasil tes pada siklus II diperoleh tingkat ketuntasan belajar siswa sebesar 93,55\% dengan tingkat ketercapaian tes hasil belajar mencapai $90 \%$ atau dengan kata lain setelah dilakukan siklus II siswa secara keseluruhan sudah mencapai standar ketuntasan belajar di atas $70 \%$.

Dari kegiatan penelitian yang telah dilaksanakan dapat disimpulkan bahwa hasil penelitian memiliki keunggulan dan kelemahan, sehingga hasil dari penelitian yang telah dilaksanakan belum sempurna dan belum optimal sesuai dengan yang diharapkan. Keunggulan dalam penelitian ini adalah sebagai berikut:
1. Siswa termotivasi dalam belajar sehingga hasil belajar siswa dapat meningkat.

2. Suasana kelas menyenangkan serta menggairahkan.

3. Terciptanya kerjasama dalam proses belajar mengajar antara siswa dengan siswa, siswa dengan guru dan guru dengan siswa.

Kelemahan dalam penelitian ini adalah sebagai berikut:

1. Dalam proses belajar mengajar siswa masih ribut.

2. Siswa tidak dibawa pada lokasi sesuai dengan konteks pembelajaran yang sedang dipelajari.

3. Siswa kurang dalam bertanya dan mengemukakan pendapat.

4. Alokasi waktu dalam melaksanakan kegiatan pembelajaran masih kurang.

5. Penelitian yang dilaksanakan tertuju pada hasil belajar belum pada penilaian proses pembelajaran.

6. Penelitian ini masih dibatasi pada kompetensi Tata Surya.

Dari hasil penelitian dan kesimpulan di atas, maka peneliti mengajukan beberapa saran sebagai berikut:

1. Dalam proses pembelajaran diharapkan siswa beraktivitas sesuai dengan materi yang dipelajari agar suasana kelas tidak ribut. 
2. Agar guru bidang studi dapat menerapkan model pembelajaran kontekstual sesuai dengan konteksnya khusus pada kompetensi Tata Surya, siswa dibawa ke lokasi pembelajaran/ sumber belajar, seperti museum dan lain sebagainya.

3. Kepada guru kelas IV supaya melatih siswa/i dalam mengajukan pertanyaan sehingga para siswa/i dapat terampil dalam bertanya.

4. Kepada pihak sekolah kiranya dapat menambah alokasi waktu pada pembelajaran sesuai dengan konteksnya, karena dalam hal ini pembelajaran membutuhkan alokasi waktu yang panjang.

\section{DAFTAR RUJUKAN}

Departemen Pendidikan Nasional Direktorat Jenderal Pendidikan Dasar dan Menengah Direktorat Pendidikan Lanjutan Pertama. 2003. Pendekatan

Kontekstual (Contextual Teaching and Learning (CTL)). Jakarta: Depdiknas.

Muhibbin Syah. 2003. Psikologi Belajar. Jakarta: Raja Grafindo Persada.

Nana Sudjana. 2008. Penilaian Hasil Proses Belajar Mengajar. Bandung: Remaja Rosda Karya.
Slameto. 1995. Belajar dan Faktorfaktor yang Mempengaruhinya. Jakarta: Rineka Cipta.

Sugiyono. 2008. Metode Penelitian Pendidikan. Bandung: Alfabeta.

Sumaji, dkk. 1998. Pendidikan Sains yang Humanitis. Yogyakarta: Kanisius. 